\title{
A study of the preconsonantal vowel shortening in Chinese*
}

\author{
Yun, Ilsung**
}

\begin{abstract}
This study aimed to examine whether preconsonantal vowel shortening, which occurs in many languages, exists in Chinese. To this end, we compared 15 pairs of Chinese bi-syllabic words with intervocalic unaspirated/aspirated stops. The results revealed that (1) the effect of the feature aspiration of the following stop on the preceding vowel (V1) was neither significant nor consistent though V1 tends to be a little longer before an unaspirated stop; (2) the following unaspirated stop closure (C) was similar to or longer than its aspirated cognate; (3) the durational sum of V1 and C was longer when the stop is unaspirated, and V1 and C had no compensatory relationship; (4) Voice Onset Time (VOT) was significantly longer when the stop is aspirated than unaspirated; (5) the vowel (V2) following VOT was significantly longer when the stop is unaspirated, so the differentials in VOT were partially compensated; (6) despite the partial compensation, the sum of VOT and V2 was longer when the stop is aspirated; (7) words with an intervocalic aspirated stop were longer than those with its unaspirated cognate. It is concluded that while VOT is the most important factor for deciding the timing structure of Chinese words with intervocalic stops, closure duration is crucial for Korean and many other languages.
\end{abstract}

Keywords: Chinese stops, preconsonantal vowel shortening, vowel, closure duration, VOT (aspiration)

\section{Introduction}

One of the phonetic and phonological phenomena observed in many languages is the preconsonantal vowel (syllable) shortening (e.g., English: House \& Fairbanks, 1953; Peterson \& Lehiste, 1960; French: Chen, 1970; Mack, 1982; Spanish: Delattre, 1962; Zimmerman \& Sapon, 1958; Norwegian: Fintoft, 1961; Dutch: Slis \& Cohen, 1969; Van den Berg, 1988; Japanese: Port, et al., 1987; Sato, 1993; Tamil: Balasubramanian, 1981; Hindi: Maddieson \& Gandour, 1975; Russian: Chen, 1970; German: Kohler, 1979;
Swedish: Carlson \& Granström, 1986; Elert, 1964; Arabic: Alghamdi, 1990; Korean: Chen, 1970; Kim, 1965; Kim, 1987; Oh, 2002; Oh \& Johnson, 1997; Yun, 2004, 2009, 2010). That is, a vowel or syllable in many languages is shorter before phonologically voiceless or tense obstruents within a syllable and/or across the syllable boundary while it is longer before their voiced or lax cognates.

On the other hand, it is surprising that few studies of Chinese have been reported with regard to the preconsonantal vowel (syllable) shortening, though Chinese is a language that is currently

\footnotetext{
* This work was supported by the Ministry of Education of the Republic of Korea and the National Research Foundation of Korea (NRF-2015S1A5B5A07042773). ** Kyung Hee University, yuis@daum.net Received 30 October 2018; Revised 26 November 2018; Accepted 30 November 2018

(c) Copyright 2018 Korean Society of Speech Sciences. This is an Open-Access article distributed under the terms of the Creative Commons Attribution Non-Commercial License (http://creativecommons.org/licenses/by-nc/4.0) which permits unrestricted non-commercial use, distribution, and reproduction in any medium, provided the original work is properly cited.
} 
used by more than 1.4 billion people even in mainland China only. The shortening has been observed in languages whose stops are distinguished by the feature \pm voice or \pm tense. Interestingly, Chinese stops are not distinguished by voicing or tenseness. They are all phonologically voiceless as Korean stops are. However, unlike Korean stops with three-way distinctions by aspiration and tenseness (Kim, 1965), they are distinguished only by the feature aspiration (Lin, 2007). Now, it is worthwhile to examine whether the preceding vowel duration varies as a function of the feature aspiration of the following stop in Chinese.

Though the preconsonantal vowel (syllable) shortening is found in many languages, the degree or pattern of the durational variation differs between languages. First, it has been known that out of many languages, English reveals the greatest variation of vowel duration as a function of the following consonant, i.e., the vowel before a voiceless consonant is much shorter than that before its voiced counterpart (Chen, 1970; Zimmerman \& Sapon, 1958). For instance, Chen (1970) calculated the average ratios of vowel duration before voiceless vs. voiced consonants in seven languages. The results showed that English had the lowest ratio: 0.61 in English, 0.87 in French, 0.82 in Russian, 0.78 in Korean, 0.90 in German, 0.86 in Spanish and 0.82 in Norwegian. However, especially the comparison between English and Korean was not fair because most of the test words in English were mono-syllabic whereas all the words were bi-syllabic in Korean. With regard to this, it should be noted that Korean stops become neutralized at coda position, i.e., no phonetic distinction between tense/lax stops (Martin, 1951). Unlike within a syllable, Korean is more remarkable than English in the variation of the preceding vowel duration across a syllable boundary (Kim, 1987; Yun, 2004, 2009, 2010).

Second, the following consonant closure duration also varies from language to language. For example, Chen (1970) reported that while the average durational ratio between English voiced consonant closures and their voiceless cognates was $1: 1.59$, it was $1: 2.3$ between Korean ones - Chen (1970) classified Korean consonants (stops and affricates) into two groups (voiced vs. voiceless) as in English. Kim (1987) observed that for English the ratio was $1: 1.22$, whereas for Korean the ratio between the three types (phonologically voiceless lax unaspirated stops $/ \mathrm{p}, \mathrm{t}, \mathrm{k} /$, voiceless tense unaspirated stops $/ \mathrm{p}^{\prime}, \mathrm{t}^{\prime}, \mathrm{k}^{\prime} /$, and voiceless tense aspirated stops $/ \mathrm{p}^{\mathrm{h}}, \mathrm{t}^{\mathrm{h}}, \mathrm{k}^{\mathrm{h}} /$ ) of stop closure durations was $1: 3.36$ : 2.52. Yun (2009) also reported that the average ratio between the three types of Korean stop closure durations was 1 (lax unaspirated) : 2.55 (unaspirated tense) : 2.14 (aspirated tense). The three studies suggest that the mean ratio between closure durations of tense vs. lax or voiceless vs. voiced consonants (stops and affricates) is much greater in Korean than in English.

Third, in English and Japanese, the preceding vowel (V) and the following stop closure (C) fully compensate for each other in duration (Port, 1981; Port, et al., 1987). That is, the micro-units (V, C) show inverse temporal variations, whereas the macro-unit $(\mathrm{V}+\mathrm{C})$ remains unchanged irrespective of the feature \pm voice of the following consonant C. In Korean, however, the sum of vowel and consonant durations differs depending on the feature \pm tense of the following consonant, i.e., $\mathrm{V}+$ tense $\mathrm{C}$ is longer than $\mathrm{V}+\operatorname{lax} \mathrm{C}$. This means that the macro-unit $\mathrm{V}+\mathrm{C}$ of Korean shows a pattern different from those of English and Japanese. The cross-linguistically different timing patterns between $\mathrm{V}$ and $\mathrm{C}$ are demonstrated in Yun (2010) where Korean, English, Japanese, and Arabic data are compared (see Figure 1). The compared data include Korean words (papa vs. pap'a vs. papa), English words (dibber vs. dipper and deeber vs. deeper) from Port (1981), Japanese words (kada vs. kata) from Port, et al. (1987), and Arabic words (badar vs. batar) from Alghamdi (1990). In Korean, solid lines with white circles indicate $\mathrm{V}$ and dotted lines VOT $+\mathrm{V}$. Solid lines with white circles indicate $\mathrm{V}$ in Arabic, but VOT $+\mathrm{V}$ in English and Japanese. Figure 1 clearly shows that Korean $\mathrm{V}$ and $\mathrm{C}$ partly compensate for each other whereas the $\mathrm{V}$ and $\mathrm{C}$ reveal full compensations in the other three languages.

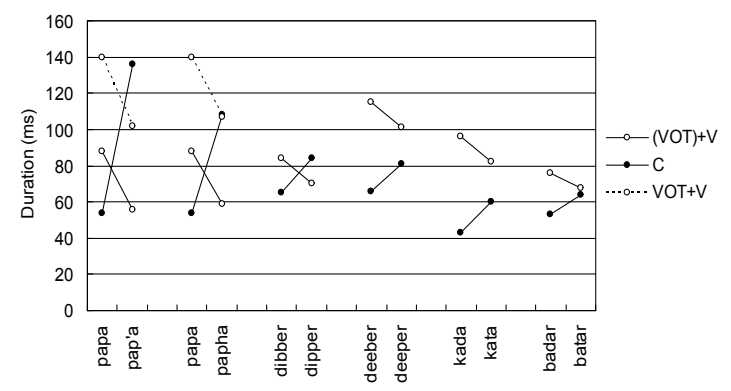

Figure 1. Comparison of durational variations between the preceding vowel (V) and the following stop closure (C) in Korean, English, Japanese and Arabic (Yun, 2010, p. 86, Figure 2)

Not only $\mathrm{V}+\mathrm{C}$ but also words with an intervocalic stop in Korean are significantly longer when the stop is tense than when it is lax. For example, Sato (1993) reported that $/ \mathrm{mamp}^{\mathrm{i}} \mathrm{i} /$ and $/ \mathrm{mamp}^{\mathrm{h}} \mathrm{i} /$, which were similar in duration, were longer than $/ \mathrm{mampi} /$. Yun (2004) also showed that /ap'a/ and / $/ \mathrm{p}^{\mathrm{h}} \mathrm{a} /$, which were similar in duration, were longer than /apa/. It is because the durational differentials in $\mathrm{V}+\mathrm{C}$ remain at word level in Korean (Yun, 2004).

As mentioned so far, many languages show the preconsonantal vowel (syllable) shortening, but the degree or pattern of temporal variation differs between languages. Chinese also must have its own typical timing pattern between $\mathrm{V}$ and $\mathrm{C}$. In order to discover the pattern, this study examined both the temporal micro-units $(\mathrm{V}, \mathrm{C}$, VOT) and macro-units $(\mathrm{V}+\mathrm{C}$, word) of Chinese.

\section{Method}

\subsection{Informants}

Five (one male and four female) native speakers of Mandarin took part in the recording. They were all undergraduate students of Hankuk University of Foreign Studies at their twenties.

\subsection{Stimuli}

As seen in Table 1, 15 pairs of bi-syllabic Chinese words were chosen as stimuli. All the words (five pairs with bilabial stops $/ \mathrm{p}$, $\mathrm{p}^{\mathrm{h}} /$; five pairs with alveolar stops $/ \mathrm{t}, \mathrm{t} /$; five pairs with velar stops $/ \mathrm{k}$, $\mathrm{k}^{\mathrm{h}} /$ ) have one of Chinese unaspirated/aspirated stops (/p, $\mathrm{p}^{\mathrm{h}}, \mathrm{t}, \mathrm{t}^{\mathrm{h}}, \mathrm{k}$, $\mathrm{k}^{\mathrm{h}} /$ ) at the onset of the second syllable. The target words were embedded in a carrier sentence, 请把 再说一遍 [qin pa zài shuō yībiàn] 'Please say again.' As a result, we obtained 30 sentences. Reading lists were prepared in which those sentences were written in ten different orders. The five informants were asked to read the lists at their normal rate to produce 1,500 tokens (5 informants $\times 30$ words $\times 10$ lists). Their speech was directly recorded into a computer through a microphone in the 
sound treated recording room of the Speech Laboratory at Hankuk University of Foreign Studies. The recording was digitised at a sampling rate of $16 \mathrm{kHz}$ with 16 bit resolution and saved as files to be processed by the software package Praat.

Table 1. Stimuli

\begin{tabular}{|c|c|}
\hline$/ \mathrm{p} /$ & $/ \mathrm{p}^{\mathrm{h} /}$ \\
\hline 老伯/lǎopó/ father's elder brother & 老婆 /lǎopó/ a wife \\
\hline 胳膊 /gēpó/ an arm & 割破 /gēph $\mathrm{h} /$ to get cut \\
\hline 隔壁 /gépì/ a neighbor's house & 革皮 /gép $\mathrm{p}_{\mathrm{i}}^{\mathrm{i}} /$ leather \\
\hline 七遍 /qīpiàn/ number 7 & 欺骗 / qīphiàn/ to cheat \\
\hline 改变 /găipiàn/ to change & 钻片 /gàiphiàn/ a calcium pill \\
\hline$/ \mathrm{t} /$ & $/ t^{\mathrm{h}} /$ \\
\hline 浦东 /pǔtōy/ a city name & 普通 /pǔt $\mathrm{t}^{\mathrm{h}} \mathrm{y} /$ commonness \\
\hline 祈䘠 /qítǎo/ to pray & 乞讨/qíthăo/ to beg for money \\
\hline 缅甸 /miăntiàn/ Myanmar & 腼腆 /miănt ${ }^{\mathrm{h}}$ iăn/ to be shy \\
\hline 省道 /shěntào/ a thoroughfare & 绳套 /shént hào/ a trap \\
\hline 替代 /titài/ to replace & 体态 /tith ài/ a body shape \\
\hline$/ \mathrm{k} /$ & $/ \mathrm{k}^{\mathrm{h}} /$ \\
\hline 投稿 /tóukăo/ a contribution & 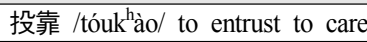 \\
\hline 国歌 /guókē/ a nation & 过客 /guòk h̀̀/ a passer-by \\
\hline 诗歌 /shīkē/ a poem & 食客 /shík è / a hanger-on \\
\hline 几个 /jìkè/ some & 饥渴 /jīk $\mathrm{h}^{\mathrm{h}} /$ hunger and thirst \\
\hline 骨骼 /kǔké/ a framework & 顾客 /kùk h̀̀/ a customer \\
\hline
\end{tabular}

\subsection{Measurement and statistics}

First, we measured the $1^{\text {st }}$ syllable duration - when the onset is a lateral /1/: /1/ + preceding vowel duration (V1); when the onset is a stop: closure duration $(\mathrm{C} 1)+\mathrm{VOT} 1+$ preceding vowel duration (V1); when the onset is an affricate (e.g., /q1//, /ji $/$ ): $\mathrm{C} 1+$ affrication (for convenience it is counted as VOT1) $+\mathrm{V} 1$; when the onset is a fricative (e.g, /shéy/, /shí/): frication + V1 (for convenience the coda $/ \mathrm{y} /$ was counted as part of $\mathrm{V} 1$ ); when the onset is a nasal (e.g., /miăn/): nasal duration $+\mathrm{V} 1$ (for convenience the final $/ \mathrm{n} /$ was counted as part of V1). Second, we measured the $2^{\text {nd }}$ syllable duration - closure duration $(\mathrm{C} 2)$ of the intervocalic stops + aspiration (VOT2) + vowel (V2) (for convenience the codas $/ \mathrm{y}, \mathrm{n} /$ were counted as part of V2). Finally, the whole word duration was measured.

We obtained averages (ms), SD and SE, with performing repeated measures ANOVAs.

\section{Results and Discussion}

\subsection{Preceding vowel: V1}

As seen in Table 2, the preceding vowel (V1) is generally longer when the intervocalic consonant is unaspirated than when it is aspirated. But statistically significant differences were observed from only two out of the 15 pairs, and even the differences were not great $(p=0.032,0.039)$. Furthermore, some vowels were longer before aspirated stops (e.g., /găipiàn/ $147 \mathrm{~ms} v s$. /gàiphiàn/ $156 \mathrm{~ms}$ ). Therefore, it can be said that overall, the effect of the feature aspiration on V1 was neither significant nor consistent though V1 is liable to be a little longer before an unaspirated stop. This means that there is no significant preconsonantal vowel shortening in Chinese.
Table 2. V1: Averages (ms), $F$ ratios, $p$-values

\begin{tabular}{|c|c|c|c|c|}
\hline Word & N.Asp & Asp & $F(1,4)$ & $p$-value \\
\hline /lăopó/ vs. /lăophó/ & 157 & 149 & 10.441 & $0.032^{*}$ \\
\hline /gēpó/ vs. /gēph̀̀/ & 151 & 145 & 1.751 & $0.256 \mathrm{~ns}$ \\
\hline /gépì/ vs. /géphi/ & 146 & 139 & 1.551 & $0.281 \mathrm{~ns}$ \\
\hline /qīpiàn/ vs. /qīphiàn/ & 91 & 79 & 9.131 & $0.039^{*}$ \\
\hline /găipiàn/ vs. /gàiphiàn/ & 147 & 156 & 4.058 & $0.114 \mathrm{~ns}$ \\
\hline /pǔtōy/ vs. /pǔthōy/ & 94 & 88 & 2.025 & $0.228 \mathrm{~ns}$ \\
\hline /qítăo/ vs. /qíthăo/ & 84 & 83 & 0.109 & $0.758 \mathrm{~ns}$ \\
\hline /miăntiàn/ vs. /miănt iăn/ & 187 & 186 & 0.012 & $0.918 \mathrm{~ns}$ \\
\hline /shěntào/ vs. /shént ào/ & 156 & 156 & 0.002 & $0.97 \mathrm{~ns}$ \\
\hline /tìtài/ vs. /tìthài/ & 95 & 79 & 3.143 & $0.151 \mathrm{~ns}$ \\
\hline /tóukăo/ vs. /tóuk ào/ & 139 & 126 & 7.1 & $0.056 \mathrm{~ns}$ \\
\hline /guókē/ vs. /guòk è/ & 156 & 144 & 3.553 & $0.133 \mathrm{~ns}$ \\
\hline /shīkē/ vs. /shíkhè/ & 97 & 94 & 0.545 & $0.501 \mathrm{~ns}$ \\
\hline /jìkè/ vs. /jīkhě/ & 101 & 113 & 2.389 & $0.197 \mathrm{~ns}$ \\
\hline /kǔké/ vs. /kùkhè/ & 133 & 123 & 4.14 & $0.112 \mathrm{~ns}$ \\
\hline
\end{tabular}

\section{2. (VOT1)+V1}

Repeated measures ANOVAs on [(VOT1)+V1] were performed in accordance with Port, et al. (1987) which regards VOT as part of the following vowel. The results were similar to those of V1 (see Table 3). That is, VOT1 (or affrication)+V1 was generally longer before unaspirated stops than aspirated ones. However, except for three pairs, the differences were not significant. In addition, two pairs showed the opposite results, i.e., /găipiàn/ (163 ms) vs. /gàip hiàn/ (172 ms); /jǐkè/ (165 ms) vs. /jīkhě/ (174 ms), and one pair had the same length, i.e., /shěntào/ (156 ms) vs. /shént h̀o/ (156 ms). To summarize, a vowel tends to be a little longer before unaspirated stops, but the trend is weak and inconsistent. It again indicates that Chinese has no significant preconsonantal vowel shortening. This is very different from English and Korean in which the distinctive feature voicing or tenseness of the following consonant causes significant durational differences in the preceding vowel.

Table 3. (VOT1)+V1: Averages (ms), $F$ ratios, $p$-values

\begin{tabular}{|c|c|c|c|c|}
\hline Word & N.Asp & Asp & $F(1,4)$ & $p$-value \\
\hline /lăopó/ vs. /lăopóo/ & 157 & 149 & 10.441 & $0.032^{*}$ \\
\hline /gēpó/ vs. /gēph ò/ & 182 & 175 & 2.289 & $0.205 \mathrm{~ns}$ \\
\hline /gépì/ vs. /gép híl/ $^{\prime}$ & 179 & 170 & 1.53 & $0.284 \mathrm{~ns}$ \\
\hline /qīpiàn/ vs. /qīphiàn/ & 220 & 201 & 13.399 & $0.022^{*}$ \\
\hline /găipiàn/ vs. /gàiphiàn/ & 163 & 172 & 3.73 & $0.126 \mathrm{~ns}$ \\
\hline /pǔtōy/ vs. /pǔthōy/ & 171 & 162 & 5.964 & $0.071 \mathrm{~ns}$ \\
\hline /qítăo/ vs. /qíthăo/ & 206 & 199 & 17.261 & $0.014^{*}$ \\
\hline /miăntiàn/ vs. /miănthiăn/ & 187 & 186 & 0.012 & $0.918 \mathrm{~ns}$ \\
\hline /shěntào/ vs. /shénthào/ & 156 & 156 & 0.002 & $0.97 \mathrm{~ns}$ \\
\hline /tìtài/ vs. /tìthài/ & 186 & 173 & 2.759 & $0.172 \mathrm{~ns}$ \\
\hline /tóukăo/ vs. /tóuk ào/ & 209 & 199 & 2.535 & $0.187 \mathrm{~ns}$ \\
\hline /guókē/ vs. /guòk ${ }^{\text {hè/ }}$ & 186 & 173 & 4.41 & $0.104 \mathrm{~ns}$ \\
\hline /shīkē// vs. /shík h̀̀̈/ & 97 & 94 & 0.545 & $0.501 \mathrm{~ns}$ \\
\hline /jükè/ vs. /jīikě/ & 165 & 174 & 2.036 & $0.227 \mathrm{~ns}$ \\
\hline /kǔké/ vs. /kùk è/ & 162 & 154 & 7.324 & $0.054 \mathrm{~ns}$ \\
\hline
\end{tabular}

\subsection{Intervocalic consonant: closure duration $(\mathrm{C} 2)$}

Closure duration (C2) of unaspirated intervocalic stops was significantly longer than that of aspirated ones in six out of the 15 pairs (see Table 4). However, the trend was not consistent. In the other nine pairs, $\mathrm{C} 2$ did not statistically differ depending on the 
feature aspiration of the intervocalic stops. C2 was even shorter in unaspirated stops than in aspirated ones in three pairs (/gēpó/ (41 ms) vs. /gēp òd (45 ms); /tìtài/ (37 ms) vs. /tìt ài/ (41 ms); /tóukăo/ (30 ms) vs. /tóuk ào/) (32 ms)), or the same in one pair (/lăopó/ (60 $\mathrm{ms})$ vs. /lăop ó/ (60 ms)). All in all, however, we can say that the closure duration of Chinese unaspirated stops is similar to or longer than that of aspirated ones.

Table 4. C2: Averages (ms), $F$ ratios, $p$-values

\begin{tabular}{|c|c|c|c|c|}
\hline Word & N.Asp & Asp & $F(1,4)$ & $p$-value \\
\hline /lăopó/ vs. /lăop ó/ & 60 & 60 & 0.000 & $0.984 \mathrm{~ns}$ \\
\hline /gēpó/ vs. /gēph ò/ & 41 & 45 & 2.638 & $0.18 \mathrm{~ns}$ \\
\hline /gépi// vs. /gép ${ }^{\text {híl/ }}$ & 46 & 40 & 5.558 & $0.078 \mathrm{~ns}$ \\
\hline /qīpiàn/ vs. /qīphiàn/ & 45 & 37 & 5.247 & $0.084 \mathrm{~ns}$ \\
\hline /găipiàn/ vs. /gàiphiàn/ & 60 & 38 & 16.64 & $0.015^{*}$ \\
\hline /pǔtōy/ vs. /pǔthōy/ & 42 & 31 & 89.542 & $0.001^{* *}$ \\
\hline /qítăo/ vs. /qit'ăo/ & 36 & 28 & 12.512 & $0.024^{*}$ \\
\hline /miăntiàn/ vs. /miănth iăn/ & 35 & 21 & 18.27 & $0.013^{*}$ \\
\hline /shěntào/ vs. /shénthào/ & 32 & 22 & 15.861 & $0.016^{*}$ \\
\hline /tìtài/ vs. /tìthài/ & 37 & 41 & 2.204 & $0.212 \mathrm{~ns}$ \\
\hline /tóukăo/ vs. /tóuk ào/ & 30 & 32 & 0.5 & $0.518 \mathrm{~ns}$ \\
\hline /guókē/ vs. /guòk è/ & 41 & 36 & 7.115 & $0.056 \mathrm{~ns}$ \\
\hline /shîkē/ vs. /shík h̀̀̈/ & 41 & 38 & 1.064 & $0.361 \mathrm{~ns}$ \\
\hline /jìkè/ vs. /jīik êt & 51 & 39 & 3.882 & $0.12 \mathrm{~ns}$ \\
\hline /kǔké/ vs. /kùk'è̀/ & 44 & 31 & 12.657 & $0.024^{*}$ \\
\hline
\end{tabular}

\section{4. (VOT1) $+\mathrm{V} 1+\mathrm{C} 2$}

As seen in Table 5, when the intervocalic stop (C2) is unaspirated, (VOT1) $+\mathrm{V} 1+\mathrm{C} 2$ was longer in seven of the 15 pairs, and it was almost significantly longer in three other pairs (/gépì/ vs. /gép $\mathrm{i}$ i/, $p=0.061$; /găipiàn/ vs. /găip ${ }^{\mathrm{h}}$ iàn/, $p=0.061$; /jîkè/ vs. /jìk $\left.\mathrm{h} \mathrm{è} /, p=0.055\right)$. In the other five pairs, (VOT1)+V1+C2 was a little longer when the stop is unaspirated, though the differences were not significant $(p>0.1)$. In conclusion, the durational unit of (VOT1) $+\mathrm{V} 1+\mathrm{C} 2$ in Chinese tends to be longer when the stop is unaspirated than aspirated.

Table 5. (VOT1) $+\mathrm{V} 1+\mathrm{C} 2$ : Averages (ms), $F$ ratios, $p$-values

\begin{tabular}{|c|c|c|c|c|}
\hline Word & N.Asp & Asp & $F(1,4)$ & $p$-value \\
\hline /lăopó/ vs. /lăophó/ & 216 & 208 & 1.496 & $0.288 \mathrm{~ns}$ \\
\hline /gēpó/ vs. /gēph ò/ & 223 & 220 & 0.51 & $0.515 \mathrm{~ns}$ \\
\hline /gépì/ vs. /gép î/ & 225 & 210 & 6.722 & $0.061 \mathrm{~ns}$ \\
\hline /qīpiàn/ vs. /qīphiàn/ & 264 & 238 & 16.74 & $0.015^{*}$ \\
\hline /găipiàn/ vs. /gàip hiàn/ & 223 & 209 & 6.685 & $0.061 \mathrm{~ns}$ \\
\hline /pǔtōy/ vs. /pǔthōy/ & 213 & 194 & 21.424 & $0.01^{*}$ \\
\hline /qítăo/ vs. /qit ăo/ & 242 & 226 & 100.829 & $0.001^{* *}$ \\
\hline /miăntiàn/ vs. /miănt'iăn/ & 222 & 207 & 11.768 & $0.027^{*}$ \\
\hline /shěntào/ vs. /shént ào/ & 189 & 178 & 47.045 & $0.002^{* *}$ \\
\hline /tìtài/ vs. /tǐthài/ & 223 & 214 & 1.815 & $0.249 \mathrm{~ns}$ \\
\hline /tóukăo/ vs. /tóuk ào/ & 239 & 231 & 2.826 & $0.168 \mathrm{~ns}$ \\
\hline /guókē/ vs. /guòk è/ & 227 & 209 & 8.755 & $0.042^{*}$ \\
\hline /shîkē/ vs. /shík h̀̀̈/ & 138 & 132 & 1.137 & $0.346 \mathrm{~ns}$ \\
\hline /jìkè/ vs. /jīkhěě/ & 216 & 213 & 7.25 & $0.055 \mathrm{~ns}$ \\
\hline /kǔké/ vs. /kùk'è̀/ & 206 & 185 & 27.904 & $0.006^{* *}$ \\
\hline
\end{tabular}

As said earlier, many languages have a compensatory temporal movement between the preceding vowel and the following consonant, whether the compensation is full or partial. However, such a compensation did hardly occur in Chinese, considering the durational variations of (VOT1) $+\mathrm{V} 1$ and $\mathrm{C} 2$ that were introduced in the previous sections. That is, regardless of statistical significance, each of the preceding vowel (VOT1)+V1 and the following consonant $(\mathrm{C} 2)$ was generally longer when the stop is unaspirated than aspirated. Therefore, the sum of (VOT1)+V1 and C2 also was longer when the stop is unaspirated. A relatively longer preceding vowel and a relatively longer following unaspirated stop made a longer duration than the duration a relatively shorter vowel and a relatively shorter aspirated stop did. Compensation between $\mathrm{V}$ and $\mathrm{C}$ takes place with a long vowel and a short consonant or with a short vowel and a long consonant. However, it did not occur in Chinese.

One pair (/kǔké/ vs. /kùk ⿳⺈ è/) out of the test words is demonstrated in Figure 2. No noticeable durational compensation is seen between $\mathrm{V}$ and $\mathrm{C}$ in Figure 2, while clear compensations are seen in the four languages in Figure 1.

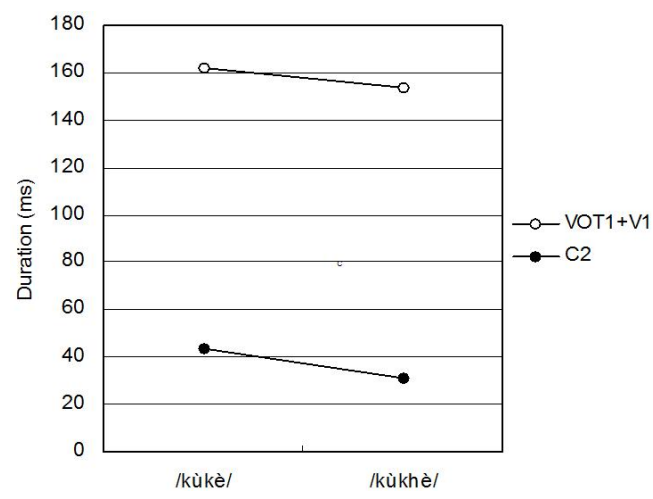

Figure 2. A comparison of durational variations between the preceding vowel (VOT1+V1) and the following stop closure (C2) in Chinese

\subsection{VOT2}

As expected, all of the 15 word pairs were significantly distinguished by VOT2 (see Table 6). This proves that aspiration is the distinctive feature of Chinese stops. Velar consonants $/ \mathrm{k}, \mathrm{k}^{\mathrm{h}} /$ had relatively longer VOTs than bilabial and alveolar stops as in other languages, e.g., Korean. In particular, unaspirated $/ \mathrm{k} /$ revealed notably longer VOTs than $/ \mathrm{p}, \mathrm{t}$.

Table 6. VOT2: Average (ms), $F$ ratios, $p$-values

\begin{tabular}{|c|c|c|c|c|}
\hline Word & N.Asp & Asp & $F(1,4)$ & $p$-value \\
\hline /lăopó/ vs. /lăop ó/ & 16 & 72 & 170.585 & $0.000^{* * *}$ \\
\hline /gēpó/ vs. /gēph ò/ & 9 & 64 & 178.84 & $0.000^{* * *}$ \\
\hline /gépì/ vs. /géphi// & 13 & 87 & 39.983 & $0.003^{* *}$ \\
\hline /qīpiàn/ vs. /qīphiàn/ & 9 & 72 & 135.903 & $0.000^{* * *}$ \\
\hline /găipiàn/ vs. /gàiphiàn/ & 7 & 70 & 144.501 & $0.000^{* * *}$ \\
\hline /pǔtōy/ vs. /pǔt ${ }^{\mathrm{h}} \mathrm{o} y /$ & 11 & 66 & 106.699 & $0.000^{* * * *}$ \\
\hline /qítǎo/ vs. /qíthăo/ & 11 & 69 & 43.268 & $0.003^{* *}$ \\
\hline /miăntiàn/ vs. /miănt tiăn/ & 17 & 69 & 502.84 & $0.000^{* * *}$ \\
\hline /shěytào/ vs. /shénttào/ & 11 & 74 & 67.38 & $0.001^{* *}$ \\
\hline /tìtài/ vs. /tìthài/ & 11 & 72 & 36.75 & $0.004^{* *}$ \\
\hline /tóukăo/ vs. /tóuk ào/ & 22 & 79 & 55.11 & $0.002^{* *}$ \\
\hline /guókē/ vs. /guòkhè/ & 34 & 83 & 76.128 & $0.001^{* *}$ \\
\hline /shīkē/ vs. /shík h̀̀ / & 29 & 85 & 270.561 & $0.000^{* * *}$ \\
\hline /jǐkè/ vs. /jīik ěc/ & 32 & 85 & 60.865 & $0.001^{* *}$ \\
\hline /kǔké/ vs. /kùkhè/ & 38 & 86 & 120.844 & $0.000^{* * *}$ \\
\hline
\end{tabular}

${ }^{*} p<0.05 ;{ }^{* *} p<0.01 ;{ }^{* * *} p<0.001$, ns: not significan 


\subsection{V2}

Repeated measures ANOVAs showed that V2 in 13 word pairs was significantly longer after unaspirated stops (see Table 7). Another pair (/tìtài/ vs. /titt ${ }^{\mathrm{h}}$ ài/), which did not significantly differ in V2, also had the same trend: V2 (/ài/) was longer after/t/ (177 ms) than after $/ \mathrm{t}^{\mathrm{h}} /(151 \mathrm{~ms})$. Those results lead to a compensatory relationship between VOT and the following V, which could be the reason why VOT is often regarded as part of the following vowel.

Table 7. V2: Averages (ms), $F$ ratios, $p$-values

\begin{tabular}{|c|c|c|c|c|}
\hline Word & N.Asp & Asp & $F(1,4)$ & $p$-value \\
\hline /lăopó/ vs. /lăop h́/ & 171 & 144 & 156.312 & $0.000^{* * *}$ \\
\hline /gēpó/ vs. /gēph̀̀/ & 145 & 146 & 0.03 & $0.87 \mathrm{~ns}$ \\
\hline /gépì/ vs. /géphi/ & 151 & 125 & 356.095 & $0.000^{* * *}$ \\
\hline /qīpiàn/ vs. /qīphiàn/ & 205 & 173 & 41.666 & $0.003^{* *}$ \\
\hline /găipiàn/ vs. /gàiphiàn/ & 200 & 168 & 23.387 & $0.008^{* *}$ \\
\hline /pǔtōy/ vs. /pǔthōy/ & 198 & 173 & 64.94 & $0.001^{* *}$ \\
\hline /qítăo/ vs. /quit ăo/ & 169 & 144 & 10.492 & $0.032^{*}$ \\
\hline /miăntiàn/ vs. /miănt thăn/ & 193 & 153 & 14.103 & $0.02^{*}$ \\
\hline /shěytào/ vs. /shént ào/ & 185 & 151 & 28.992 & $0.006^{* *}$ \\
\hline /tìtài/ vs. / trithài/ $^{\mathrm{h}_{\text {a }}}$ & 177 & 151 & 4.183 & $0.11 \mathrm{~ns}$ \\
\hline /tóukăo/ vs. /tóuk hào/ & 169 & 145 & 11.754 & $0.027^{*}$ \\
\hline /guókē/ vs. /guòkhè/ & 161 & 136 & 36.527 & $0.004^{* *}$ \\
\hline /shīkē/ vs. /shík hè/ & 170 & 142 & 91 & $0.001^{* *}$ \\
\hline /jūkè/ vs. /jīikě/ & 171 & 126 & 18.193 & $0.013^{*}$ \\
\hline /kǔké/ vs. /kùk è/ & 171 & 139 & 16.739 & $0.015^{*}$ \\
\hline
\end{tabular}

\subsection{VOT2+V2}

Statistical analyses proved that VOT2+V2 in 12 pairs was significantly longer when the intervocalic stop is aspirated than unaspirated (see Table 8). In the other three pairs also, VOT2+V2, if not significant, was longer after an aspirated stop. This means that the opposite durational variations of VOT and V2 only partly compensate for each other.

Table 8. VOT2+V2: Average (ms), $F$ ratios, $p$-values

\begin{tabular}{|c|c|c|c|c|}
\hline Word & N.Asp & Asp & $F(1,4)$ & $p$-value \\
\hline /lăopó/ vs. /lăophó/ & 187 & 216 & 27.238 & $0.006^{* *}$ \\
\hline /gēpó/ vs. /gēph ò/ & 154 & 209 & 356.258 & $0.000^{* * *}$ \\
\hline /gépì/ vs. /gép ${ }^{\mathrm{h}} \mathrm{i} /$ & 164 & 211 & 15.45 & $0.017^{*}$ \\
\hline /qīipiàn/ vs. /qīphiàn/ & 214 & 245 & 159.477 & $0.000^{* * *}$ \\
\hline /găipiàn/ vs. /gàip hiàn/ & 207 & 238 & 178.332 & $0.000^{* * *}$ \\
\hline /pǔtōy/ vs. /pǔthōn/ & 209 & 239 & 17.016 & $0.015^{*}$ \\
\hline /qítăo/ vs. /qitithăo/ & 180 & 213 & 45.274 & $0.003^{* *}$ \\
\hline /miăntiàn/ vs. /miănthiăn/ & 210 & 223 & 1.3 & $0.318 \mathrm{~ns}$ \\
\hline /shěntào/ vs. /shéntthào/ & 196 & 225 & 57.236 & $0.002^{* *}$ \\
\hline /titài/ vs. /titthài// & 188 & 224 & 11.729 & $0.027^{*}$ \\
\hline /tóukăo/ vs. /tóuk hào/ & 190 & 224 & 35.999 & $0.004^{* *}$ \\
\hline /guókē/ vs. /guòkhè/ & 196 & 219 & 81.955 & $0.001^{* *}$ \\
\hline /shīkē/ vs. /shík'è/ & 199 & 227 & 92.769 & $0.001^{* *}$ \\
\hline /jìkè/ vs. /jīkhě/ & 203 & 211 & 2.411 & $0.195 \mathrm{~ns}$ \\
\hline /kǔké/ vs. /kùk'è/ & 209 & 225 & 4.862 & $0.092 \mathrm{~ns}$ \\
\hline
\end{tabular}

\subsection{Word duration}

Repeated measures ANOVAs yielded that words with an intervocalic aspirated stop were significantly longer than those with its unaspirated cognate in eight pairs (see Table 9). The other seven pairs also generated a little longer word durations when the intervocalic stop is aspirated. In Korean, the feature tenseness causes significant differentials between tense and lax stop closure durations, and the differentials contribute to significant durational differences between words with tense/lax intervocalic stops (Yun, 2010). In Chinese, VOT following intervocalic stop closure functions like Korean stop closure though its effect on word duration is not so strong or consistent as Korean stop closure.

Table 9. Word duration: Averages (ms), $F$ ratios, $p$-values

\begin{tabular}{|c|c|c|c|c|}
\hline Word & N.Asp & Asp & $F(1,4)$ & $p$-value \\
\hline /lăopó/ vs. /lăophó/ & 466 & 488 & 13.78 & $0.021^{*}$ \\
\hline /gēpó/ vs. /gēph ò/ & 440 & 491 & 101.119 & $0.001^{* *}$ \\
\hline /gépì/ vs. /géphi// & 446 & 474 & 4.412 & $0.104 \mathrm{~ns}$ \\
\hline /qīipiàn/ vs. /qīip iàn/ & 517 & 523 & 0.624 & $0.474 \mathrm{~ns}$ \\
\hline /găipiàn/ vs. /gàiphiàn/ & 473 & 502 & 13.079 & $0.022^{*}$ \\
\hline /pǔtōy/ vs. /pǔthōy/ & 481 & 489 & 0.73 & $0.441 \mathrm{~ns}$ \\
\hline /qítăo/ vs. /qit ăo/ & 462 & 479 & 13.185 & $0.022^{*}$ \\
\hline /miăntiàn/ vs. /miănthiăn/ & 517 & 519 & 0.012 & $0.917 \mathrm{~ns}$ \\
\hline /shěntào/ vs. /shént thò/ & 494 & 516 & 30.344 & $0.005^{* *}$ \\
\hline /tìtài// vs. /tìthài/ & 461 & 477 & 0.743 & $0.437 \mathrm{~ns}$ \\
\hline /tóukăo/ vs. /tóuk ào/ & 466 & 494 & 37.851 & $0.004^{* *}$ \\
\hline /guókē/ vs. /guòk è̀/ & 476 & 491 & 9.615 & $0.036^{*}$ \\
\hline /shīkē/ vs. /shík hèe & 493 & 522 & 10.719 & $0.031^{*}$ \\
\hline /jǔkè/ vs. /jīikně/ & 463 & 474 & 7.398 & $0.053 \mathrm{~ns}$ \\
\hline /kǔké/ vs. /kùk'è/ & 467 & 471 & 0.188 & $0.687 \mathrm{~ns}$ \\
\hline
\end{tabular}

As seen in the previous sections, the preceding vowel (VOT1)+V1 and the following intervocalic consonant $\mathrm{C} 2$ were generally longer when the stop is unaspirated, and so was their sum (VOT1) $+\mathrm{V} 1+\mathrm{C} 2$. In addition, V2 after VOT2 was generally longer when the intervocalic stop is unaspirated. Thus, the durational units before and after VOT2 varied to reduce the differences between VOT2s of unaspirated/aspirated stops. Nevertheless, words with an intervocalic aspirated stop were often significantly longer than those with its unaspirated cognate. It suggests that VOT2 is crucial to word duration in Chinese.

\section{Summary and Conclusion}

This study compared 15 pairs of bi-syllabic Chinese words with intervocalic unaspirated/aspirated stops to verify whether Chinese has the preconsonantal vowel shortening that is observed in many languages. The results were (1) preceding vowel shortening hardly occurred as a function of the feature aspiration of the following stop, (2) the following unaspirated stop closure (C) was similar to or longer than its aspirated cognate, (3) the preceding vowel duration (VOT1) $+\mathrm{V} 1$ and the following intervocalic stop closure duration $\mathrm{C} 2$ had no compensatory relationship unlike in other languages, e.g., Korean, English, Japanese, and Arabic where a long preceding vowel is followed by a short stop closure and vice versa. Rather, both the preceding vowel and the following stop closure tended to be longer when the intervocalic stop is unaspirated; so, the sum of the vowel duration and closure duration was also longer when the stop is unaspirated, (4) VOT2 was significantly longer when the stop is aspirated than when unaspirated, (5) V2 following VOT2 was significantly longer when the intervocalic stop is unaspirated, 
and it partly compensated for the differential between VOT2s before $\mathrm{V} 2$, (6) despite the partial compensation, VOT2+V2 was longer when the intervocalic stop is aspirated, (7) words with an intervocalic aspirated stop were longer than those with its unaspirated cognate though the differences were not always significant. This implies that the longer aspiration (VOT2) in words with an aspirated stop was not well absorbed by the other components of the words. Considering all, we can say that while VOT is the most important factor for deciding the timing structure of Chinese words with intervocalic stops, closure duration is crucial for Korean and many other languages. The language specific pattern of the preconsonantal vowel shortening should be incorporated into the phonology of Chinese.

On the other hand, Chinese stops seem to be all tense as well as voiceless. First, impr essionistically Chinese unaspirated stops sound like Korean tense unaspirated stops, while Chinese aspirated stops sound like Korean tense aspirated stops. Second, Chinese unaspirated/aspirated stops were often similar in duration though unaspirated stops were sometimes longer. Third, the effects of the following unaspirated/aspirated stops on the preceding vowel (VOT1)+V1 were generally similar, i.e., the duration of (VOT1)+V1 remained similar irrespective of the feature of the following stops. Therefore, if duration is a realization of utterance energy, Chinese unaspirated/aspirated stops are likely to have a similar degree of tenseness. Of course, whether Chinese stops are all tense or not, the feature tenseness does not distinguish Chinese stops as voicing does not.

\section{References}

Alghamdi, M. M. A. (1990). Analysis, synthesis and perception of voicing in Arabic. Ph.D. Thesis, University of Reading, UK.

Balasubramanian, T. (1981). Duration of vowels in Tamil. Journal of Phonetics, 9(2), 151-161.

Carlson, R., \& Granström, B. (1986). A search for durational rules in a real-speech data base. Phonetica, 43(1-3), 140-154.

Chen, M. (1970). Vowel length variation as a function of the voicing of the consonant environment. Phonetica, 22(3), 129-159.

Delattre, P. (1962). Some factors of vowel duration and their cross-linguistic validity. The Journal of the Acoustical Society of America, 34(8), 1141-1142.

Elert, C. C. (1964). Phonologic studies of quantity in Swedish: Based on material from Stoskholm speakers. Uppsala: Almqvist \& Wiksell.

Fintoft, K. (1961). The duration of some Norwegian speech sounds. Phonetica, 7(1), 19-39.

House, A. S., \& Fairbanks, G. (1953). The influence of consonant environment upon the secondary acoustical characteristics of vowels. Journal of the Acoustical Society of America, 25(1), 105-113.

Kim, C. W. (1965). On the autonomy of the tensity feature in stop classification (with special reference to Korean stops). Word, 21(3), 339-359.

Kim, D. W. (1987). Some phonetic aspects of intervocalic oral stop consonants in British English and Korean. Ph.D. Thesis, University of Reading, UK

Lin, Y. H. (2007). The sounds of Chinese. Cambridge: Cambridge University Press.

Mack, M. (1982). Voicing-dependent vowel duration in English and
French: Monolingual and bilingual production. Journal of the Acoustical Society of America, 71(1), 173-178.

Maddieson, I., \& Gandour, J. (1975). Vowel length before stops of contrasting series. Journal of the Acoustical Society of America, 58(S1), S61.

Martin, S. E. (1951). Korean phonemics. Language, 27, 519-532.

Oh, E. J. (2002). Correlation between consonants' place and vowel duration in English and Korean. Speech Sciences, 9(3), 201-210.

Oh, M., \& Johnson, K. (1997). A phonetic study of Korean intervocalic laryngeal consonants. Speech Sciences, 1(1), 83-102.

Peterson, G. E., \& Lehiste, I. (1960). Duration of syllable nuclei in English. Journal of the Acoustical Society of America, 32(6), 693-703.

Port, R. F. (1981). Linguistic timing factors in combination. Journal of the Acoustical Society of America, 69(1), 262-274.

Port, R. F., Dalby, J., \& O'Dell, M. (1987). Evidence for moratiming in Japanese. Journal of the Acoustical Society of America, 81(5), 1574-1585.

Sato, Y. (1993). The durations of syllable-final nasals and the mora hypothesis in Japanese. Phonetica, 50(1), 44-67.

Slis, I. H., \& Cohen, A. (1969). On the complex regulating the voiced-voiceless distinction I. Language and Speech, 12(2), 80-102.

Van den Berg, R. J. H. (1988). The perception of voicing in Dutch two-obstruent sequences: A comparison of synthetic and natural speech. Journal of Phonetics, 16(2), 171-180.

Yun, I. (2004). Temporal variation due to tense vs. lax consonants in Korean. Speech Sciences, 11(3), 23-36.

Yun, I. (2009). Vowel duration and the feature of the following consonant. Phonetics and Speech Sciences, 1(1), 41-46.

Yun, I. (2010). Compensation in VC and word. Phonetics and Speech Sciences, 2(3), 81-89.

Zimmerman, S. A., \& Sapon, S. M. (1958). Note on vowel duration seen crosslinguistically. Journal of the Acoustical Society of America, 30(2), 152-153.

\author{
- Yun, Ilsung \\ Lecturer, College of Liberal Arts \\ Kyung Hee University \\ Secheon-dong, Gihueng-gu \\ Youngin-si, Gyeonggi-do \\ 446-701, Korea \\ E-mail: yuis@daum.net \\ Fields of interest: Phonetics, Phonology
}

